\title{
A rubric study for the evaluation of caricature creation building skills of 6th grade students
}

\section{APA Citation:}

\author{
Musa Çifci a ${ }^{*}$ (iD), Kadir Kaplan ${ }^{\text {b }}$ iD \\ ${ }^{a}$ Uşak University Education Faculty, Uşak ,64000, Turkey

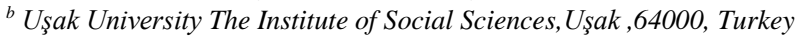

Çiftçi,, M.\& Kaplan, K. (2020). A rubric study for the evaluation of caricature creation building skills of 6th grade students. Journal of Language and Linguistic Studies, 16(1), 213-237. Doi: 10.17263/jlls.712767

Submission Date:26/09/2019

Acceptance Date:07/03/2020

\begin{abstract}
This study aimed to develop "Caricature Creation Rubric" which can be used to evaluate the products produced by 6 th grade students at the end of their caricature creation process and to make its validity and reliability studies. The criteria in the graded key were determined by using the "Caricature Literacy Module" prepared by the researcher. Following the performance definitions, a pilot application was conducted to another group apart from the study group in order to increase the validity of the graded scoring key. The pilot study was carried out with six girls and one boy, who were capable of creating caricatures and were in the same class level as the study group. The necessary corrections were made in line with the feedback received from the pilot application and the validity and reliability studies of the graded scoring key were started. The data obtained for the reliability of the rubric which was specially developed by the researcher was used to evaluate the skill of creating caricatures. For the reliability the consistency between the scores given by two different evaluators was examined. For this purpose, the Pearson Momentum Multiplication Correlation Coefficient formula was used for the consistency between the total scores obtained from the graded scoring key according to different evaluators and the consistency between the scores for each sub-group. As a result, it was seen that the rubric which was developed to evaluate caricature creation skills can be used to measure and evaluate the caricature creation works of 6th grade students.
\end{abstract}

(C) 2020 JLLS and the Authors - Published by JLLS.

Keywords: Caricature Literacy; Caricature Creation; Rubric / Graded Scoring Key

\section{Introduction}

Research on education emphasizes the effect of supporting the entertaining side of learning in obtaining permanent information and argues that knowledge is more permanent in the mind when individuals learn with fun. For this reason, learning environments, materials used in education have been differentiating in recent years and are moving away from the standard line. As a reflection of this change, interest in the use of visual materials in educational environments has increased in recent years.

"Corresponding author. Tel.: 02762212121

E-mail address: musacifci@gmail.com 


\subsection{Literature Review}

Caricature, which dates back to Paleolithic Age, is one of the educational materials, we often have seen in educational environments in recent years because it allows learners to think with fun, develop their communication skills and prevent negative attitudes students towards the courses (Palaz, Kilcan, \& Köroğlu, 2015).

Derived from the Italian word "caricare" (Topuz, 1986), caricature means exaggeration, the act of loading. Caricature as a visual material is a rich, versatile and remarkable material. The question "What is caricature?" has been answered with different definitions in the literature. The humorous, remarkable aspect of the event or situation to be taken as the basis (Avşar, 2007), thought and humor melted in a ladle and depicted in a pot (Akkaya, 2011), human or goods exaggerated description (K1lınc K., 2006), live or inanimate humor (Palaz, Kılcan, \& Köroğlu, 2015), which is based on exaggerating and drawing comic aspects of beings in a way, is a very powerful branch of art that describes everything with lines (Dokgöz, 2006), visual elements in textbooks (Kabapınar, 2003).

The diversity in its definition is also seen in caricature genres and there are many caricature classifications in the literature: Özşahin (2009) divides caricatures into three categories: political, humorous-comic and explanatory. He states that political caricatures deal with current affairs and are based on humor and criticism. The illustrative caricature emphasizes that products are mostly focused on advertising and teaching materials. Kazanevsky (2005) classifies caricatures as caricatures which convey the philosophical problems of people, criticize the social structure of society and include humor. Avşar (2007); art, idea and humor. The art, caricature and humor that he considers as the main components of caricature; indicates that it is not possible to create caricatures. Uslu's (2007) classification varies according to the type of material used in caricature, technique and fiction structure characteristics of caricature. According to the materials used, the caricatures are separated in black and white according to the technique and they are divided into single frames, vignettes and bands.

Considering the common features of these classifications, caricature types can be examined under four headings:
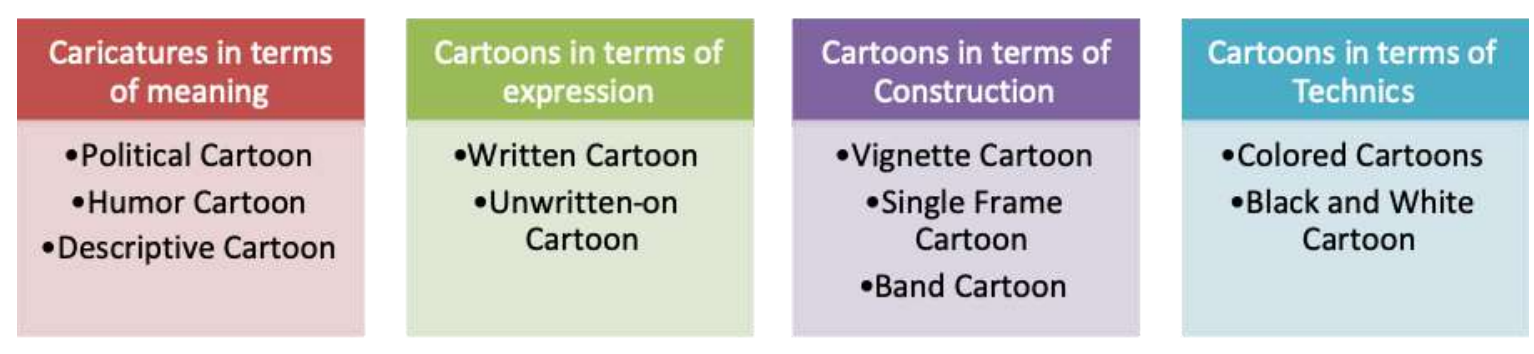

The mission of education is quite big in developing individuals' knowledge and skills and in making these knowledge and skills permanent. In order to realize the mission of education, educational programs, acquisitions and tools are needed. One of these tools is caricature; even one of the most influential because of its educational function (Uslu, 2007) caricatures.

When the studies related to caricature are examined, it is seen that the success in teaching increases when many courses are supported with caricatures. Social Studies education (Akengin \& İbrahimoğlu, 2010; Durualp, 2006; Aksoy, Karatekin, Kuş, \& Sönmez, 2010; Sidekli, Er, Yavaşer \& Aydın, 2014); History education (Kılınç, 2006); Science education (Köse, 2008; Balım, İnel \& Evrekli, 2008; Kabapınar, 2003; Oluk \& Özalp, 2007) Citizenship and Democracy education (Uygun \& Üztemür 2015), Turkish Language and Literature (Üstün, 2007), Mathematics education (Uğurel) \& Moralı, 2006) Biological education (Kılınç \& Salman, 2006; Köse, 2008) in the field of caricature-supported 
training in favor of the experimental group and the effect of using caricature as a teaching material was revealed.

In the literature, when we categorize the studies conducted in Turkish education, it has been shown that caricatures improve vocabulary (Varışoğlu, Şeref, Gedik, \& Yılmaz, 2014; Mürsel, 2009; Kıvrak, 2016; Topal, 2007); contribution to written expression skills (Üstün, 2007); that it provides significant advantages in terms of teaching difficulties in language and grammar teaching (Delp \& Jones, 1996; Morris, Merrit, Fairclough, Birrell, \& Howitt, 2007) and its impact on academic achievement (Başarmak \& Mahiroğlu, 2016; Savaş, 2014; Rule \& Schneider, 2009). Yaman, 2010; Saat, Er, \& Üstten, 2018; Wright, 2003); There are studies on the effect of preschool students on speaking and listening skills (Akran \& Kocaman, 2018).

There are many reasons why caricatures are preferred as instructional materials in educational environments. Although these reasons vary according to the subject area, caricatures have interdisciplinary characteristics. Because of the interdisciplinary characteristics of caricatures, it is preferred to use caricature as a teaching material in many different fields.

Humor is one of the main features. The humor feature emerges as an important force in terms of motivating students in the educational environment. Through the caricature, an educational environment is created in which students learn while having fun.

Caricature facilitates communicating and enables students to express themselves better and encourages students with lack of self-confidence (Haugaard, 1973). One of the contributions of caricatures to individuals as instructional material is to develop individuals' problem-solving skills and encourage them to think critically.

Caricatures are seen by educational technologists as key to a better science education (Copenhaver, 2005). In the studies carried out in the literature, caricature's contributions to educational environments are described as follows:

- As it contains materials for different types of intelligence, it has the feature of facilitating remembering. In this respect, caricatures directly contribute to the permanence of learning.

- The development of oral and written communication skills of the students can be ensured through oral and written expression studies carried out during the activities of meaning making caricature.

- At the core of the caricature is a critical approach to individual or social events. This critical approach enables individuals to approach social events from a critical perspective and become aware of critical thinking.

- Through caricature, which is one of the visual material types, individuals discover their interest in this field and also develop their aesthetic tastes.

- Another benefit of using caricature in educational environments is that it embodies abstract knowledge and contributes to the permanence of learning and shortens the time spent for learning.

- Caricature is an important element in controlling the cognitive understanding as well as improving the skill of literacy.

- Caricature contributes to students' thinking skills by enhancing their creativity and discovering their abilities.

- When used as a caricature educational material, it provides the opportunity to bring current events and popular culture products to the classroom. 
- Caricatures can be used to comprehend the subject as well as the stages of preparation to the course or the determination of students' readiness, and to draw attention to the subject (Vogler, 2004; Cho \& Reich, 2008; Keogh \& Naylor, 1999; Morrison, Bryan, \& Chilcoat, 2002; Kleeman, 2006).

In language teaching, caricatures have the competence to serve this purpose when used correctly and in place. Göçer and Akgül (2018) state that caricatures can be used in the acquisition of basic skills, especially writing skills. It is stated that caricatures can also be used in grammar teaching due to the difficulty of grammar issues and being based on memorization (Akkaya, 2011). Savaş (2014) examined the effect of the visual materials with humor element on their attitudes towards the Turkish course and stated that the attitude group mean scores of the experimental group were higher than the mean scores of the control group towards the Turkish lesson. It is seen that the intensity of using caricature in Turkish education is in the field of teaching Turkish to foreigners (Özkan, 2009; Melanlıoğlu, Tayşi, \& Özdemir, 2012).

As a result, caricatures; it is very effective in making sense of information, organizing and linking different information. Because of these properties, it is one of the original material types that can be used in education.

Gradual scoring keys, which are used in the field of education dating back 40-50 years, are scoring tools that set the evaluation criteria in the measurement process. This measurement tool designed to evaluate performance is called a graded scoring key or rating scale in our country. Andrade (1997) defines the scoring instrument in which the criteria for what is important in the study are clearly laid out.

The difference of the graded scoring key from other measurement tools is that it has teaching feature as well as measuring feature. It is a measurement tool that directly contributes to the performance of the students because it sets the criteria for performance evaluation and shows how to reach the criteria (Karamanoğlu, 2006). The Graded Scoring Key is a tool that enables quick and objective evaluation of performance levels with many different characteristics, from written or oral presentation to laboratory activities. Students have the opportunity to see what they are missing and see what they are doing right and are motivated. Because, in each stage, the content of the stage is indicated besides the score that the student will receive.

Mertler (2001), before preparing a graded scoring key "What criteria will be evaluated according to the performance, what will be looked at when determining the success in the specified criteria, what will be the difference between a good work and an inadequate work, how the headlight will be defined, how the assessment is valid and reliable will be taken? " questions.

Aslanoğlu \& Kutlu (2003) state that graded scoring keys consist of three parts: evaluation criteria, criteria definitions and scoring strategy. When preparing these three sections, firstly performance is chosen. At this stage, the performance of the student is determined. The dimensions of the selected performance are then determined. At this stage, the sub-skills necessary for the successful acceptance of the student are explained.

The performance levels are determined after the sub-skills are identified. Number or descriptive expressions are used when showing the performance level. In some graded scoring keys, both number and descriptive expression can be used together. Levels are determined from the lowest to the most successful performance.

After determining the performance levels, performance definitions are written for each level separately. First, the most successful performance level and the lowest performance level are defined. Then the definition of intermediate levels is made. 
There are two types of graded keys, analytical -depending on the performance to be observed in the students- and holistic.

In holistic evaluation, the outcome is more important than the process. Different levels of performance are defined superficially. Performance is evaluated as a whole without being disassembled. Suitable for superficial and short-term evaluation purposes. Superficial performance levels such as high level, developed and inadequate are determined.

Korkmaz (2009) recommends that holistic assessment should be made especially when the teacher prepares a graded key for performance for the first time, when there is a need for short-term evaluation, and when it is difficult to divide performance into dimensions.

They are directives where the process is at the forefront rather than the result, and different levels of performance are defined clearly and in detail.

Korkmaz (2009) recommends that analytical evaluation should be performed when there is a need for a long-term evaluation, when the performance is multidimensional, and when the dimensions are easy to grade.

The scores obtained from each department as a result of scoring according to the definition of performance are determined by the student's performance level and total score.

There are some points that need to be considered in order to achieve the purpose of using graded scoring key and to evaluate students' performance objectively. Moskal (2003) states that when developing a graded key, the criteria should be observed between the criteria of performance and the target, the criteria should be observable, and the language and scoring used should be understood.

There are many studies on the development of graded scoring keys. Andrade (1997) states that there are stages of Developing Samples, Listing Criteria, Expressing Qualifications Degrees, Applying on Samples, Using Individual and Group Assessment, Reviewing, Using Teacher Assessment e stages in developing graded key.

In the first stage, the characteristics of the study are defined based on the sample student work of similar task. When the criteria are listed, criteria list is created based on the specified features. When preparing qualifications, first the most successful and the most unsuccessful performance grades are written and then the intermediate level performances are written. Initially, a graded scoring switch is tried on the samples. After the trial, grading scoring key is evaluated. If necessary, the teacher applies the rubric to the students after the necessary arrangements are made through the review.

The constructivist approach affected both the curriculum and the assessment approach. Measurement and evaluation changed from the result-based approach to the process-based approach, and the student's progress in the process started to be taken into consideration while the student's success continued to be assessed with a grade. Thus, the students actively participated in the evaluation process.

The contribution of graded scoring to students is not limited to this. With the use of a graded scoring key, students can better understand the content of their performance and produce more successful products. Shepard (2000) therefore sees rubric as a source of understanding and understanding, not as a source of reward or punishment. Feedback in the nature of rubric makes learning easier.

The use of a graded scoring key contributes to the students' ability to exhibit critical approaches, cause and effect relationships, being open to different ideas and data-based evaluation (Y1ld1z, 2005). With this contribution to the use of graded scoring key, students will be equipped with 21 st century skills.

The use of a graded scoring key also benefits teachers. It provides the objectivity of the assessment process for the teacher as well as the progress and deficiencies of the students. In addition, it allows 
teachers to see the impact of the methods and techniques they use to get feedback instantly (Y1ldiz, 2005). This paves the way for the evaluation process to be completed sooner.

New approaches in measurement and evaluation emphasize knowledge and skill practices and students can structure information in the face of problems (Korkmaz, 2009). At this point, the graded scoring key as a new assessment approach is noteworthy as an important assessment tool.

\section{Method}

This research was carried out to develop a measurement tool to determine the caricature creation skills of individuals. In order for the feature to be studied in a scientific way, it is very important that the relevant feature is measurable and that there is a standard measurement tool. In this study, validity and reliability procedures (calculations) were performed in order to develop a scale that was designed as a graded scoring key, which measures the students' caricature creation skills.

\subsection{Sample / Participants}

The study group consisted of sixth grade students attending a secondary school in the central district of Afyonkarahisar. The preliminary application was carried out with 7 students, 6 of whom were girls and 1 of them were boys. The working group of the general application consists of 107 students. 57 of the students are female and 50 are male. Table 1 presents the descriptive values of the students in the study group.

Table 1. Distribution of Students in the Working Group by Gender

\begin{tabular}{lccc}
\hline Group & Sex & $\mathrm{N}$ & $\mathrm{N}$ (total) \\
\hline $\begin{array}{l}\text { Preliminary } \\
\text { Application }\end{array}$ & Girl & 6 & 7 \\
\hline Beneral & Boy & 1 & \\
Application & Girl & 57 & \\
& Boy & 50 & 107 \\
\hline
\end{tabular}

\subsection{Instrument( $(s)$}

The students were asked to answer twenty-seven open-ended questions about Content Creation, Presenting Valid and Reliable Information, Creating Effective Presentations which were prepared by using the Caricature Literacy Module, and then these answers were evaluated with a graded scoring key.

Before the "Caricature Literacy Caricature Creation Scale" was created, the type of graded scoring key was chosen for the purpose of the study. After determining the type of scoring key, the subdimensions of the performance to be evaluated were determined. Successful and unsuccessful performance levels were determined for the sub-dimensions. The score levels of the performance levels were determined as 4 points for successful performance and 1 point for insufficient points. Then, the performance definition of each criterion was made. 
Table 2. Distribution of Scores of Developed Grade Scoring Key

\begin{tabular}{cc}
\hline Total Score & Qualitative Expression \\
\hline 19 & Poor \\
$20-38$ & Developable \\
$39-57$ & Good \\
$58-76$ & Very Good \\
\hline
\end{tabular}

Graded scoring key consists of nineteen criteria and three parts including: "creating caricatures for the purpose", "considering the target audience", "choosing the appropriate type of caricature for the determined purpose", "using the refractive lines of the caricature", "creating text based on the caricature", "using art elements and design principles", "reorganizing caricatures", "creating caricatures appropriate to the theme and subject", "reflecting the current themes to the caricatures", "caricaturing what you listen", "caricaturing the text you read", "caricaturing emotions, thoughts, dreams, information and impressions", "realizing the function of laws that organize perception, "using persuasion and propaganda techniques", "distinguishing between information and interpretation", "questioning the accuracy of the created material", "questioning the validity and reliability of visual material", "applying ethical and legal principles while creating visual material" and "selecting visual materials appropriate for the purpose. The specification table of the Caricature Literacy-Caricature Forming Scale is presented below:

Table 3. Caricature Creation Scale Specification Table

\begin{tabular}{|c|c|c|c|}
\hline Learning Area & Goal & Related Gain & Item Number \\
\hline \multirow{16}{*}{ 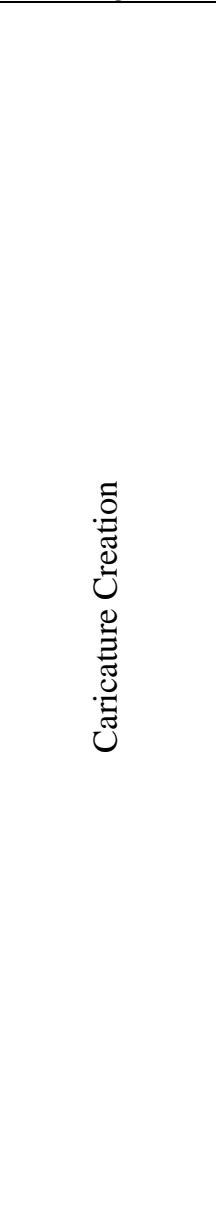 } & \multirow{14}{*}{$\begin{array}{l}\text { Content } \\
\text { Creation }\end{array}$} & Creates caricatures for the purpose. & 1 \\
\hline & & $\begin{array}{l}\text { Evaluates a number of variables belonging to the target } \\
\text { group when creating caricatures. }\end{array}$ & 2 \\
\hline & & $\begin{array}{l}\text { Select the appropriate caricature type for the specified } \\
\text { purpose. }\end{array}$ & 3 \\
\hline & & Uses refraction lines in caricature creation. & 4 \\
\hline & & Creates text based on caricatures. & 5 \\
\hline & & $\begin{array}{l}\text { Uses art elements and design principles in creating visual } \\
\text { art works. }\end{array}$ & 6 \\
\hline & & $\begin{array}{l}\text { Reorganizes caricatures to convey emotions, thoughts, } \\
\text { dreams and impressions. }\end{array}$ & 7 \\
\hline & & $\begin{array}{l}\text { Creates caricatures from ideas in line with the theme and } \\
\text { topic determined. }\end{array}$ & 8 \\
\hline & & Reflects current events to the caricature. & 9 \\
\hline & & $\begin{array}{l}\text { Uses visualization strategy to make sense of what they listen } \\
\text { during and after listening. }\end{array}$ & 10 \\
\hline & & $\begin{array}{l}\text { Uses visualization strategy to make sense of text during and } \\
\text { after reading. }\end{array}$ & 11 \\
\hline & & $\begin{array}{l}\text { It visualizes emotions, thoughts, dreams, knowledge and } \\
\text { impressions through caricatures. }\end{array}$ & 12 \\
\hline & & $\begin{array}{l}\text { Realize the function of laws that organize the perception } \\
\text { used in the perception of visual materials in material } \\
\text { creation. }\end{array}$ & 13 \\
\hline & & $\begin{array}{l}\text { Uses the elements of persuasion and propaganda suitable for } \\
\text { the purpose of creating caricatures. }\end{array}$ & 14 \\
\hline & \multirow{2}{*}{$\begin{array}{l}\text { Presenting Valid } \\
\text { and Reliable } \\
\text { Information }\end{array}$} & $\begin{array}{l}\text { Distinguishes the information in the content of the material } \\
\text { and the interpretation while creating a caricature. }\end{array}$ & 15 \\
\hline & & $\begin{array}{l}\text { Question the accuracy of the material created by creating } \\
\text { caricatures from different materials. }\end{array}$ & 16 \\
\hline
\end{tabular}




\begin{tabular}{|l|l|l|l|}
\hline & $\begin{array}{l}\text { Discusses the credibility of the source on which the } \\
\text { caricature is based. }\end{array}$ & 17 \\
\cline { 2 - 4 } & Applies ethical rules when creating caricatures. & 18 \\
\hline & $\begin{array}{c}\text { Creating } \\
\text { Effective } \\
\text { Presentations }\end{array}$ & $\begin{array}{l}\text { Content in the presentation creates the harmony of } \\
\text { caricatures. }\end{array}$ & 19 \\
\hline
\end{tabular}

The levels in determining student achievement has been graded as follows; performance with significant shortcomings (1 point)", limited performance to improve ( 2 points)", "successful performance (3 points)" and "excellent performance (4points). The sum of the scores obtained from the criteria constitutes the achievement grade for the student's ability to create caricatures. Since there are nineteen criteria and four achievement levels in the key, the highest score is 76 and the lowest score is 19. The graded scoring key is attached.

\subsection{Data Collection Procedures}

In order to increase the reliability of the graded scoring key, the sample performances used in different studies were examined. Expert opinion was taken for definition of criteria and content. Following the performance definitions, a pilot application was conducted to increase the validity of the graded scoring key to another group outside the study group. The pilot study was carried out with a total of seven students, six girls and one boy, who were capable of creating caricatures and were in the same class level as the study group. The necessary corrections were made in line with the feedback received from the pilot application and the validity and reliability studies of the graded scoring key were started.

The general implementation was realized in the second semester of the 2018-2019 academic year. Since the aim of developing a scale is to apply it to a group with similar characteristics, it is very important to select individuals who will represent the group's range at a good level and to take part in the trial implementation of these individuals (Erkuş, 2016). This will ensure that the item statistics of the scale are more accurate. In order to calculate the reliability coefficient of the graded scoring key for caricature creation skills, a group of students studying in a public school in Afyonkarahisar city center were applied in general. Volunteerism and heterogeneous distribution were taken into consideration in the determination of the sample and easily accessible sample selection technique was used since the researcher applied the trial application at the school where he worked. In the trial application of the scale, Pituch \& Stevens (2006) 5-20 person formula was used for the variable (item) and the scale was applied to 107 participants. $\mathrm{N}=107$ sample size and scale development analyzes were started.

\subsection{Data Analysis}

The reliability studies of the prepared graded key were conducted. The answers of the students to nineteen open-ended questions about Content Creation, Presenting Valid and Reliable Information, Creating Effective Presentations which were prepared by using Caricature Literacy Module were evaluated by two different evaluators using graded scoring keys. The data obtained in relation to the results were evaluated in SPSS 18.0 statistical program. For the reliability of the prepared scoring key, the consistency between the scores given by two different evaluators was examined.

According to the "Central Limit Theorem, the total or arithmetic mean showing the same and independent distribution converges to the normal distribution provided that the sample size is 30 and above. On the other hand, as the sample grows without considering the distribution of the population, the shape of the distribution approaches to normal and the validity and reliability levels of inferences increase (Levine, Ramsey and Smidt, 2001). For this reason, the Pearson Momentum Multiplication 
Correlation Formula was used for the total scores obtained from the graded scoring key according to different evaluators and for the consistency between the scores made for each sub-dimension.

\section{Results}

The results of the Pearson momentum multiplication correlation coefficient, which are made to determine the consistency between the total scores obtained from the graded scoring key according to two different evaluators, are given in the table.

Table 4. Correlation results of the total scores obtained from the graded key according to two different evaluators

\begin{tabular}{|c|c|c|c|}
\hline \multicolumn{2}{|c|}{ (Pearson Product Momentum Correlation) } & First Reviewer Ratings & Second Reviewer Ratings \\
\hline \multirow{3}{*}{ First Reviewer Ratings } & $\begin{array}{c}\text { Correlation } \\
\text { Coefficient (r) }\end{array}$ & 1 & $.851^{* *}$ \\
\hline & $\mathrm{p}$ & & .000 \\
\hline & $\mathrm{N}$ & 107 & 107 \\
\hline \multirow{3}{*}{ Second Reviewer Ratings } & $\begin{array}{c}\text { Correlation } \\
\text { Coefficient (r) }\end{array}$ & $.851^{* *}$ & 1 \\
\hline & $\mathrm{P}$ & .000 & \\
\hline & $\mathrm{N}$ & 107 & 107 \\
\hline
\end{tabular}

As it is seen in the table, there is a significant, positive and high relationship between the scores given by the first evaluator and the total scores given by the second evaluator $(r=0.851, p<0,05)$. There is a high correlation between the scores given by two different evaluators using the graded scoring key to the caricature creation test questions. This indicates that the graded scoring key is sufficiently reliable. According to Büyüköztürk (2004), Pearson momentum multiplication correlation coefficient (r) can be defined as a high level relationship if the absolute value is greater than 0.70 .

The results of the Pearson momentum multiplication correlation coefficient for determining the consistency between the scores obtained from each item of the graded scoring key according to two different evaluators are given in the table.

Table 5. Correlation results of the scores obtained from each item of the graded scoring key according to two different evaluators

\begin{tabular}{|c|c|c|c|}
\hline \multicolumn{2}{|c|}{ (Pearson Product Moment Correlation) } & First Reviewer Ratings & Second Reviewer Ratings \\
\hline \multirow{3}{*}{$\begin{array}{l}\text { First Reviewer Ratings to } \\
\text { M1 }\end{array}$} & Correlation Coefficient (r) & 1 &, $747^{* *}$ \\
\hline & $\mathrm{p}$ & &, 000 \\
\hline & $\mathrm{N}$ & 107 & 107 \\
\hline \multirow{3}{*}{$\begin{array}{l}\text { Second Reviewer } \\
\text { Ratings to M1 }\end{array}$} & Correlation Coefficient (r) &, $747^{* *}$ & 1 \\
\hline & $\mathrm{p}$ &, 000 & \\
\hline & $\mathrm{N}$ & 107 & 107 \\
\hline \multirow{3}{*}{$\begin{array}{l}\text { First Reviewer Ratings } \\
\text { to M2 }\end{array}$} & Correlation Coefficient (r) & 1 & $743^{* *}$ \\
\hline & $\mathrm{p}$ & &, 000 \\
\hline & $\mathrm{N}$ & 107 & 107 \\
\hline \multirow{3}{*}{$\begin{array}{l}\text { Second Reviewer } \\
\text { Ratings to M2 }\end{array}$} & Correlation Coefficient (r) &, $743^{* *}$ & 1 \\
\hline & $\mathrm{p}$ &, 000 & \\
\hline & $\mathrm{N}$ & 107 & 107 \\
\hline \multirow{3}{*}{$\begin{array}{l}\text { First Reviewer Ratings } \\
\text { to M3 }\end{array}$} & Correlation Coefficient (r) & 1 &, $738^{* *}$ \\
\hline & $\mathrm{p}$ & &, 000 \\
\hline & $\mathrm{N}$ & 107 & 107 \\
\hline
\end{tabular}




\begin{tabular}{|c|c|c|c|}
\hline \multirow{3}{*}{$\begin{array}{l}\text { Second Reviewer } \\
\text { Ratings to M3 }\end{array}$} & Correlation Coefficient (r) & $.738^{* *}$ & 1 \\
\hline & $\mathrm{p}$ & .000 & \\
\hline & $\mathrm{N}$ & 107 & 107 \\
\hline \multirow{3}{*}{$\begin{array}{l}\text { First Reviewer Ratings } \\
\text { to M4 }\end{array}$} & Correlation Coefficient (r) & 1 & $.740^{* * *}$ \\
\hline & $\mathrm{p}$ & & .000 \\
\hline & $\mathrm{N}$ & 107 & 107 \\
\hline \multirow{3}{*}{$\begin{array}{l}\text { Second Reviewer } \\
\text { Ratings to M4 }\end{array}$} & Correlation Coefficient (r) & $.740^{* *}$ & 1 \\
\hline & $\mathrm{p}$ & .000 & \\
\hline & $\mathrm{N}$ & 107 & 107 \\
\hline \multirow{3}{*}{$\begin{array}{l}\text { First Reviewer Ratings } \\
\text { to M5 }\end{array}$} & Correlation Coefficient (r) & 1 & $.722^{* * *}$ \\
\hline & $\mathrm{P}$ & & .000 \\
\hline & $\mathrm{N}$ & 107 & 107 \\
\hline \multirow{3}{*}{$\begin{array}{l}\text { Second Reviewer } \\
\text { Ratings to M5 }\end{array}$} & Correlation Coefficient (r) & $.722^{* *}$ & 1 \\
\hline & $\mathrm{p}$ & .000 & \\
\hline & $\mathrm{N}$ & 107 & 107 \\
\hline \multirow{3}{*}{$\begin{array}{l}\text { First Reviewer Ratings } \\
\text { to M6 }\end{array}$} & Correlation Coefficient (r) & 1 & $.743^{* *}$ \\
\hline & $\mathrm{P}$ & & .000 \\
\hline & $\mathrm{N}$ & 107 & 107 \\
\hline \multirow{3}{*}{$\begin{array}{l}\text { Second Reviewer } \\
\text { Ratings to M6 }\end{array}$} & Correlation Coefficient $(\mathrm{r})$ & $.743^{* *}$ & 1 \\
\hline & $\mathrm{p}$ & .000 & \\
\hline & $\mathrm{N}$ & 107 & 107 \\
\hline \multirow{3}{*}{$\begin{array}{l}\text { First Reviewer Ratings } \\
\text { to M7 }\end{array}$} & Correlation Coefficient (r) & 1 & $.744^{* *}$ \\
\hline & $\mathrm{P}$ & & .000 \\
\hline & $\mathrm{N}$ & 107 & 107 \\
\hline \multirow{3}{*}{$\begin{array}{l}\text { Second Reviewer } \\
\text { Ratings to M7 }\end{array}$} & Correlation Coefficient (r) & $.744^{* *}$ & 1 \\
\hline & $\mathrm{p}$ & .000 & \\
\hline & $\mathrm{N}$ & 107 & 107 \\
\hline \multirow{3}{*}{$\begin{array}{l}\text { First Reviewer Ratings } \\
\text { to M8 }\end{array}$} & Correlation Coefficient (r) & 1 & $.723^{* * *}$ \\
\hline & $\mathrm{P}$ & & .000 \\
\hline & $\mathrm{N}$ & 107 & 107 \\
\hline \multirow{3}{*}{$\begin{array}{l}\text { Second Reviewer } \\
\text { Ratings to M8 }\end{array}$} & Correlation Coefficient (r) & $.723^{* *}$ & 1 \\
\hline & $\mathrm{p}$ & .000 & \\
\hline & $\mathrm{N}$ & 107 & 107 \\
\hline \multirow{3}{*}{$\begin{array}{l}\text { First Reviewer Ratings } \\
\text { to M9 }\end{array}$} & Correlation Coefficient (r) & 1 & $.730^{* * *}$ \\
\hline & $\mathrm{P}$ & & .000 \\
\hline & $\mathrm{N}$ & 107 & 107 \\
\hline \multirow{3}{*}{$\begin{array}{l}\text { Second Reviewer } \\
\text { Ratings to M9 }\end{array}$} & Correlation Coefficient (r) & $.730^{* *}$ & 1 \\
\hline & $\mathrm{p}$ & .000 & \\
\hline & $\mathrm{N}$ & 107 & 107 \\
\hline \multirow{3}{*}{$\begin{array}{l}\text { First Reviewer Ratings } \\
\text { toM10 }\end{array}$} & Correlation Coefficient (r) & 1 & $.760^{* * *}$ \\
\hline & $\mathrm{P}$ & & .000 \\
\hline & $\mathrm{N}$ & 107 & 107 \\
\hline \multirow{3}{*}{$\begin{array}{l}\text { Second Reviewer } \\
\text { Ratings to M10 }\end{array}$} & Correlation Coefficient (r) & $.760^{* *}$ & 1 \\
\hline & $\mathrm{p}$ & .000 & \\
\hline & $\mathrm{N}$ & 107 & 107 \\
\hline \multirow{3}{*}{$\begin{array}{l}\text { First Reviewer Ratings } \\
\text { to M11 }\end{array}$} & Correlation Coefficient (r) & 1 & $.705^{* * *}$ \\
\hline & $\mathrm{P}$ & & .000 \\
\hline & $\mathrm{N}$ & 107 & 107 \\
\hline \multirow{3}{*}{$\begin{array}{l}\text { Second Reviewer } \\
\text { Ratings to M11 }\end{array}$} & Correlation Coefficient (r) & $.705^{* *}$ & 1 \\
\hline & $\mathrm{p}$ & .000 & \\
\hline & $\mathrm{N}$ & 107 & 107 \\
\hline \multirow{3}{*}{$\begin{array}{l}\text { First Reviewer Ratings } \\
\text { to M12 }\end{array}$} & Correlation Coefficient (r) & 1 & $.706^{* *}$ \\
\hline & $\mathrm{P}$ & & .000 \\
\hline & $\mathrm{N}$ & 107 & 107 \\
\hline & Correlation Coefficient $(\mathrm{r})$ & $.706^{* *}$ & 1 \\
\hline Ratinos to M12 & $\mathrm{P}$ & .000 & \\
\hline & $\mathrm{N}$ & 107 & 107 \\
\hline & Correlation Coefficient (r) & 1 & $.924^{* *}$ \\
\hline
\end{tabular}




\begin{tabular}{|c|c|c|c|}
\hline \multirow{2}{*}{$\begin{array}{l}\text { First Reviewer Ratings } \\
\text { to M13 }\end{array}$} & $\mathrm{P}$ & & .000 \\
\hline & $\mathrm{N}$ & 107 & 107 \\
\hline \multirow{3}{*}{$\begin{array}{l}\text { Second Reviewer } \\
\text { Ratings to M13 }\end{array}$} & Correlation Coefficient (r) & $.924^{* *}$ & 1 \\
\hline & $\mathrm{P}$ & .000 & \\
\hline & $\mathrm{N}$ & 107 & 107 \\
\hline \multirow{3}{*}{$\begin{array}{l}\text { First Reviewer Ratings } \\
\text { to M14 }\end{array}$} & Correlation Coefficient (r) & 1 & $.740^{* *}$ \\
\hline & $\mathrm{P}$ & & .000 \\
\hline & $\mathrm{N}$ & 107 & 107 \\
\hline \multirow{3}{*}{$\begin{array}{l}\text { Second Reviewer } \\
\text { Ratings to M14 }\end{array}$} & Correlation Coefficient (r) & $.740^{* *}$ & 1 \\
\hline & $\mathrm{P}$ & .000 & \\
\hline & $\mathrm{N}$ & 107 & 107 \\
\hline \multirow{3}{*}{$\begin{array}{l}\text { First Reviewer Ratings } \\
\text { to M15 }\end{array}$} & Correlation Coefficient (r) & 1 & $.838^{* *}$ \\
\hline & $\mathrm{P}$ & & .000 \\
\hline & $\mathrm{N}$ & 107 & 107 \\
\hline \multirow{3}{*}{$\begin{array}{l}\text { Second Reviewer } \\
\text { Ratings to M15 }\end{array}$} & Correlation Coefficient (r) & $.838^{* *}$ & 1 \\
\hline & $\mathrm{P}$ & .000 & \\
\hline & $\mathrm{N}$ & 107 & 107 \\
\hline \multirow{3}{*}{$\begin{array}{l}\text { First Reviewer Ratings } \\
\text { to M16 }\end{array}$} & Correlation Coefficient (r) & 1 & $.750^{* *}$ \\
\hline & $\mathrm{P}$ & & .000 \\
\hline & $\mathrm{N}$ & 107 & 107 \\
\hline \multirow{3}{*}{$\begin{array}{l}\text { Second Reviewer } \\
\text { Ratings to M16 }\end{array}$} & Correlation Coefficient (r) & $.750^{* *}$ & 1 \\
\hline & $\mathrm{P}$ & .000 & \\
\hline & $\mathrm{N}$ & 107 & 107 \\
\hline \multirow{3}{*}{$\begin{array}{l}\text { First Reviewer Ratings } \\
\text { to M17 }\end{array}$} & Correlation Coefficient (r) & 1 & $.784^{* *}$ \\
\hline & $\mathrm{P}$ & & .000 \\
\hline & $\mathrm{N}$ & 107 & 107 \\
\hline \multirow{3}{*}{$\begin{array}{l}\text { Second Reviewer } \\
\text { Ratings to M17 }\end{array}$} & Correlation Coefficient (r) & $.784^{* *}$ & 1 \\
\hline & $\mathrm{P}$ & .000 & \\
\hline & $\mathrm{N}$ & 107 & 107 \\
\hline \multirow{3}{*}{$\begin{array}{l}\text { First Reviewer Ratings } \\
\text { to M18 }\end{array}$} & Correlation Coefficient (r) & 1 & $.710^{* *}$ \\
\hline & $\mathrm{P}$ & & .000 \\
\hline & $\mathrm{N}$ & 107 & 107 \\
\hline \multirow{3}{*}{$\begin{array}{l}\text { Second Reviewer } \\
\text { Ratings to M18 }\end{array}$} & Correlation Coefficient (r) & $.710^{* *}$ & 1 \\
\hline & $\mathrm{P}$ & .000 & \\
\hline & $\mathrm{N}$ & 107 & 107 \\
\hline \multirow{3}{*}{$\begin{array}{l}\text { First Reviewer Ratings } \\
\text { to M19 }\end{array}$} & Correlation Coefficient (r) & 1 & $.708^{* * *}$ \\
\hline & $\mathrm{P}$ & & .000 \\
\hline & $\mathrm{N}$ & 107 & 107 \\
\hline \multirow{3}{*}{$\begin{array}{l}\text { Second Reviewer } \\
\text { Ratings to M19 }\end{array}$} & Correlation Coefficient (r) & $.708^{* *}$ & 1 \\
\hline & $\mathrm{P}$ & .000 & \\
\hline & $\mathrm{N}$ & 107 & 107 \\
\hline
\end{tabular}

As it is seen in the table, there is a positive, significant and high-level relationship between the scores given by the evaluators to each item of the graded scoring key ( $r>0.70, p<0.05)$. When the consistency of the scores given to the graded scoring key is examined, it is seen that the highest relationship is in 13 Article 130 (0.924) and the lowest relationship is in 11 Article $110,(0.705)$.

The results of the Pearson Momentum Multiplication Correlation Coefficient to determine the consistency between the scores obtained from each sub-dimension of the graded scoring key according to two different evaluators are given in the table: 
Table 6. Correlation results of the scores obtained from the sub-dimensions of the scoring key according to two different evaluations

\begin{tabular}{|l|l|l|r|}
\hline \multirow{2}{*}{ Size } & $\begin{array}{l}\text { (Pearson Product Moment } \\
\text { Correlation) }\end{array}$ & First Reviewer Ratings & Second Reviewer Ratings \\
\hline \multirow{2}{*}{ Content knowledge } & Correlation Coefficient (r) & 1 & $.844^{* *}$ \\
\cline { 2 - 4 } & $\mathrm{P}$ & & .000 \\
\hline $\begin{array}{l}\text { Providing Valid and } \\
\text { Reliable Information }\end{array}$ & Correlation Coefficient (r) & 1 & $.797^{* * *}$ \\
\cline { 2 - 4 } $\begin{array}{l}\text { Creating Effective } \\
\text { Presentations }\end{array}$ & $\mathrm{P}$ Correlation Coefficient (r) & 1 & .000 \\
\cline { 2 - 4 } & $\mathrm{P}$ & 107 & $.708^{* *}$ \\
\cline { 2 - 4 } & $\mathrm{N}$ & 1000 \\
\hline$* * \mathrm{p}<0.05$ is significant. & & 107 \\
\hline
\end{tabular}

As seen in the table, there is a positive, significant and high-level relationship between the scores given by two different evaluators in all sub-dimensions ( $r>0.70, \mathrm{p}<0.05)$. When the consistency of the scores given to the graded scoring key is examined, it is seen that the highest relationship is in the "Content information" sub-dimension (0.844) and the lowest relationship is in the Effective presentation creation" dimension (0.708).

\section{Discussion}

In this research, analytical rubric has been developed for the measurement and evaluation of caricature creation skills. The results obtained from the development and application of the rubric for caricature creation skills are presented below:

The answers of the students to nineteen open-ended questions about Content Creation, Presenting Valid and Reliable Information, Creating Effective Presentations which were prepared by using Caricature Literacy Module were evaluated by two different evaluator using graded scoring keys. For the reliability of the prepared scoring key, the consistency between the scores given by two different evaluators was examined.

There is a significant, positive and high relationship between the scores given by the first evaluator and the total scores given by the second evaluator $(r=0.851, \mathrm{p}<0.05)$.

There is a positive, significant and high correlation between the scores given by the evaluators to each item of the graded scoring key. When the consistency of the scores given to the graded scoring key is examined, it is seen that the highest relationship is in "Article $13,9(0.924)$ and the lowest relationship is in 11 Article $110,(0.705)$.

There was a positive, significant and high correlation between the scores given by two different evaluators in all sub-dimensions $(r>0.70, p<0.05)$. When the consistency of the scores given to the graded scoring key is examined, it is seen that the highest relationship is in the "Content information" sub-dimension (0.844) and the lowest relationship is in the Effective presentation creation" dimension (0.708).

\section{Conclusions}

After all these validity and reliability procedures, it can be said that the graded scoring key prepared to create a caricature is a valid and reliable measurement tool that can be used to determine the caricature creation skills of students. 
There are some factors that limit the results of the studies. Therefore, a clear evaluation cannot be made by taking into account the results of the research and the results of the research must be confirmed.

In this study, the analysis of the graded scoring key developed for evaluating students' cartooning skills was carried out with a sample group specified in the study. For this reason, the fact that the validity and reliability study of the scale could not be performed with 6th grade students outside the study group can be considered as an important limitation of the scale.

Another limitation of the study is that the study group was selected only from Afyonkarahisar province. Therefore, the sample kept in studies of Turkey's wider to cover the different regions will give clearer results for scale.

One of the limitations of the study is the application of the scale to the grade 6 as a grade level. In this context, the scale developed by the researcher can be applied in grades 5, 7 and 8 , and the results can be evaluated separately.

\section{Ethics Committee Approval}

The authors confirm that ethical approval was obtained from Uşak University the Committee for Research and Publication Ethics in the Social Sciences and Humanities (Approval Date: 11/10/2019 and Number 2019-50).

\section{Acknowledgements}

This study was carried out as a doctoral thesis prepared by Kadir Kaplan and executed by Prof. Dr. Musa Çifci.

\section{References}

Akengin, H., \& İbrahimoğlu, Z. (2010). Effects of Use of Cartoons in Social Studies Course on Students' Academic Achievement and Their Opinions about the Course. Educational Faculty Journal of Ondokuz Mayls University, 29(2), 1-19.

Akkaya, A. (2011, June 15). Teaching Grammar with Cartoons. Ph.D Thesis. Konya, Turkey: Selçuk University Graduate School of Educational Sciences.

Akran, S. K., \& Kocaman, İ. (2018). The Effect of Caricature Based Learning-Teaching Model on Pre-School Students' Speaking and Listening Skills. E-International Journal of Educational Research, 9(2), 105-122.

Aksoy, B., Karatekin, K., Kuş, Z., \& Sönmez, Ö. F. (2010). The Effects of Using Cartoons on Students' Academic Achievement in Social Studies Education. 9th National Symposium on Primary School Teacher Education. Elazığ: Firat Universty.

Andrade, H. G. (1997). Understanding Rubrics. Educational Leadership, 54(4), 1-7.

Aslanoğlu, A. E., \& Kutlu, Ö. (2003). A Research on the Use of Graded Scoring Switch (Rubric) in the Evaluation of Presentation Skills in Teaching. Ankara Universty Journal of Faculty of Educational Sciences , 25-36.

Avşar, S. (2007). The Use of Cartoons in Teaching History. Master's Thesis. Ankara: Gazi Universty Institute of Educational Sciences. 
Balım, A. G., İnel, D., \& Evrekli, E. (2008). The Effects the Using of Concept Cartoons in Science Education on Students' Academic Achievements and Enquiry Learning Skill Perceptions. Elementary Education Online, 7(1), 188-202.

Başarmak, U., \& Mahiroğlu, A. (2016). The Effect of Online Learning Environment Based on Caricature Animation Used in Course. The Turkish Online Journal of Educational Technology, 15(4), 107-118.

Baykul, Y. (2010). Measurement in Education and Psychology. Ankara: Pegem Academy Publishing.

Cho, S., \& Reich, G. A. (2008). New Immigrants, New Challenges: High School Social Studies Teachers and English Language Learner Instruction. The Social Studies, 99(6), 235-242.

Copenhaver, L. (2005). Cartoons Touted to Learn Science . Tucson Citizen Newspaper, 5A.

Coşar, S. (2005). Scondary School Turkish Language and Literature Class the Education of Literaty Arts. Master's Thesis. Çanakkale: Çanakkale Onsekiz Mart University.

Delp, C., \& Jones, J. (1996). Communicating Information to Patients: The Use of Cartoon Illustrations to Improve Comprehension of Instructions. Academic Emergency Medicine, 3(3), 264-270.

Dokgöz, H. (2006). An Art That Describes Everything with Lines Cartoon. Actual Medicine, 78-80.

Durualp, E. (2006). The Usage of Caricature in Teaching Social Studies at Junior High School. Master's Thesis. Ankara: Gazi Universty Institute of Educational Sciences.

Ercan, İ., \& Kan, İ. (2004). Reliability and Validity in The Scales. Journal of Uludag University Medical Faculty, 30(3), 211-216.

Erkuş, A. (2016). Measurement and Scale Development in Psychology-I Basic Concepts and Operations. Ankara: Pegem Academy Publishing.

Göçer, A. (2014). Measurement and Evaluation in Turkish Education. Ankara: Pegem Academy Publishing.

Göçer, A., \& Akgül, O. (2018). Use of Cartoons in Turkish Education and Educational Value. Journal of Language Education and Research, 4(2), 86-100.

Güler, N. (2019). Measurement and Evaluation in Education. Ankara: Pegem Academy Publishing.

Haugaard, K. (1973). Comic Books: Conduits to Culture? International Literacy Association and Wiley, 27(1), 54-55.

Kabapınar, F. (2003). Visual Elements in Turkish and English Science and Chemistry Textbooks to Reflect Constructivist Understanding. Hacettepe University Journal of Education, 25, 119-126.

Kar, İ. (2004). The Humor and Cartoon Duo...The Heir of Humor Cartoon. Retrieved from http://www.nd-karikaturvakfi.org.tr/katalog2004.htm.

Karamanoğlu, S. S. (2006). Assesing Primary Students Success in Science Courses Via Primary Years Programme: Portfolio. Master's Thesis. İstanbul: Marmara Institute of Educational Sciences.

Katipoğlu, M., Eken, Z., \& Körbay, M. (2017). The Effect of Mathematics Instruction Concucted with Comics Including Fun and Humor on Students Mathematics Achievement and Mathematics Anxiety. International Journal of Education, Science and Technology, 3(1), 32-45.

Kazanevsky, V. (2005). Specific Features of Cartoon Art in Eastern European Countries. 4th International Ankara Cartoon Festival (p. 27-29). Ankara: Cartoon Foundation. 
Keogh, B., \& Naylor, S. (1999). Concept Cartoons, Teaching and Learning in Science: An Evaluation. International Journal of Science Education, 21(4), 431-446.

Kilınç, A., \& Salman, S. (2006). Cartoon Based Learning in Biology Education. VII. National Science and Mathematics Education Congress (s. 93). Ankara: Gazi Universty.

Kılınç, K. (2006). The Effect of Using Caricature as a Material on the Success of Student in History Teaching. Master's Thesis. Ankara: Gazi University Institute of Educational Sciences Department of Secondary Social Education History Teaching.

Kivrak, D. (2016). Activity Suggestion for Improving the Vocabulary: One Caricature, One Painting. Journal of Inquiry Based Activities, 6(2), 89-96.

Kleeman, G. (2006). Using Cartoons to Investigate Social and Environmental Issues. Ethos: Journal of the Society for Psychological Anthropology, 14(3), 9-19.

Korkmaz, Y. (2009). The Effect of Use of the Rubric Trainnig in Science Education on Teacher Perceptions and Applications Regarding Measurement and Evaluation. Master's Thesis. Konya: Selcuk University Graduate School of Natural and Applied Sciences Primary Education Branch of Main Sciences.

Köse, E. Ö. (2008). The Effect of Cartoon Aided Teaching on Student Success in Biology Education . Journal of Contemporary Education, 33(356), 14-21.

Levine, D. M., Ramsey, P. P., \& Smidt, R. K. (2001). Applied Statistics for Engineers and Scientists: Using Microsoft Excel \& Minitab (1. b.). New Jersey: Prentice Hall.

Melanlığlu, D., Tayşi, E. K., \& Özdemir, B. (2012). The Use of Cartoons in Teaching Turkish as a Foreign Language. Journal of Mustafa Kemal Universty Social Sciences Institute, 9(19), 241-256.

Mertler, C. A. (2001). Designing Scoring Rubrics for Your Classroom. Practical Assessment, Research \& Evaluation, 7(25), 1-8.

Morris, M., Merrit, M., Fairclough, S., Birrell, N., \& Howitt, C. (2007). Trialling Concept Cartoons in Early Childhood Teaching and Learning of Science. Teaching Science, 53(2), 42-45.

Morrison, T. G., Bryan, G., \& Chilcoat, G. W. (2002). Using Student-Generated Comic Books in the Classroom. Journal of Adolescent \& Adult Literacy, 45(8), 758-767.

Moskal, B. M. (2003). Recommendations for Developing ClassroomPerformance Assessments and Scoring Rubrics. Practical Assessment, Research \& Evaluation, 8(14), 1-5.

Mürsel, C. G. (2009). The Effectiveness of Cartoons on Idiom and Proverbs Teaching. Master's Thesis. Ankara: Ankara Universty Institute of Educational Sciences.

Oluk, S., \& Özalp, I. (2007). The Teaching of Global Environmental Problems According to the Constructivist Approach: As a Focal Point of the Problem and the Availability of Concept Cartoons. Educational Sciences in Theory and Practice, 7(2), 850-875.

Özgüven, İ. E. (2012). Psychological Tests (11 b.). Ankara: Nobel Academic Publishing.

Özkan, P. A. (2009). Use of Caricatures in Turkish as a Foreign Language Classes with the Aim of Teaching Intercultural Communicative Competence. Master's Thesis. İstanbul: Istanbul University Institute of Social Sciences Department of Educational Sciences Department of Teaching Turkish as a Foreign.

Özşahin, E. (2009). Caricatures with Geography Education . The Magazine of Marmara Geography(20), 101-122. 
Palaz, T., Kılcan, B., \& Köroğlu, Z. Ç. (2015). Cartoon Based Learning-Teaching Approach. G. Ekici within, Current Learning-Teaching Approaches-II (s. 128-167). Ankara: Pegem Academy .

Pituch, K. A., \& Stevens, J. P. (2006). Applied Multivariate Statistics for the Social Sciences. New York: Routledge.

Rule, A. C., \& Schneider, J. S. (2009). Creating, Evaluating, and Improving Humorous Cartoons Related to Design Principles for Gifted Education Programs. University of Northern Iowa Interdisciplinary Research Symposium. Cedar Falls, Iowa: University of Northern Iowa.

Saat, H., Er, M., \& Üstten, A. U. (2018). An Application on the Contribution of the Caricature to Grammar Learning Knowledge Skills in Level a in Turkish Teaching for Foreigners. Journal of World of Turks, 10(3), 200-217.

Savaş, S. (2014). The Effects of the Use of Humor at Seventh Grade on Student Attitude in Turkish Courses. Journal of Mother Tongue Education, 2(1), 73-88.

Shepard, L. A. (2000). The Role of Assessment in a Learning Culture. Educational Researcher, 29(7), 4-14.

Sidekli, S., Er, H., Yavaşer, R., \& Aydın, E. (2014). An Alternative Method in Social Studies Education: Cartoon . International Turkish Education Journal of Science, 2(2), 151-163.

TDK (1998). Turkish Dictionary . Ankara: Turkish Language Institution. On July 17, 2018 Retrieved from Turkish Language Society:

http://www.tdk.gov.tr/index.php?option=com_bilimsanat\&arama=kelime\&guid=TDK.GTS.5b4df3 d5921693.54769702.

Topal, Y. (2007). Effect of Teaching Language Variable on Student Succes in Teaching of Turkish as a Foreign Language. Ph.D Thesis, 1876-1880. Atatürk University Institute of Social Sciences Department of Turkish Education.

Topuz, H. (1986). Cartoon and Society in Communication. Eskiş̧ehir: Anadolu University Printing House.

Uğurel, I., \& Moralı, S. (2006). Cartoons and Their Use in Mathematics. Journal of National Education, 32-46.

Uslu, H. (2007). Cartoon in Education. The Journal of Education in Science and Intelligence, 84(7), 15-18.

Uygun, K., \& Üztemur, S. S. (2015). The Effect of Use of Caricature on Students Academic. Journal of Educational Sciences, 222-234.

Üstün, Ö. (2007). The Effect of Caricatures on Written Expression in Turkish Language and Literature Lesson for Third Grades in Secondary School. Master's Thesis. Çanakkale: Çanakkale Onsekiz Mart University Institute of Social Sciences Department of Turkish Language and Literature.

Varışoğlu, B., Şeref, İ., Gedik, M., \& Yılmaz, İ. (2014). The Effect of Cartoons as a Visual Tool in the Success of Teaching Idioms and Proverbs. Journal of The Black Sea Studies, 41, 226-242.

Vogler, K. (2004). Using Political Cartoons to Improve Your Verbal Questioning. The Social Studies, 95, 11-15.

Wright, A. (2003). Pictures for Language Learning. Cambridge: Cambridge University Press.

Yaman, H. (2010). Cartoons as a Teaching Tool: A Research on Turkish Language Grammar Teaching. Educational Sciences: Theory \& Practic, 1231-1242. 
Yıldız, N. (2005). Rubric Method Self-Assessment Study in 6th Grade Science Course. Best Practices in Education Conference. İstanbul.

\section{Cartoon Reference}

https://www.aa.com.tr/tr/yasam/baris-mesajini-dunyaya-karikaturle-veriyor/754821

https://haydardirici.wordpress.com/2017/02/23/besinci-zindan/

http://handegrafik.blogspot.com/2013/03/gestalt-kuram_27.html

https://www.uludagsozluk.com/k/t\%C3\%BCrkiye-nin-kitap-sat\%C4\%B1\%C5\%9F-okuma-ve-

kitap\%C3\%A7\%C4\%B1-haritas\%C4\%B1/

http://tbm.org.tr/media/kitaplar/TBM_ilkokul_saglik_icerik_web.pdf

https://i.pinimg.com/originals/4f/a6/c9/4fa6c9bfffc80919c74109db94e59547.jpg

https://www.bestcartoons.net/Client-Area/Car/Alive-Contests/Simavi-2001/i-ccCcJvc

https://www.dijitalders.com/sunu/93/kitap_okumanin_onemi.html

\section{Appendix}

\section{A. Cartoon Literacy Cartoon Creation Skill Scale}

\section{CARTOON LITERACY CARTOON CREATION SKILL SCALE}

Dear Students,

This study is designed to measure your ability to create cartoons. Please respond by carefully reading all the contents. This is not an assessment tool for an exam or a Turkish course. Your responses to these articles will only be used for scientific purposes. When answering questions, you are not expected to reveal a perfect work of art in your drawings. Just make simple drawings (Stickman). Try to answer every question if possible. Thank you for your contribution to the research.

Postgraduate Kadir KAPLAN

\section{PERSONAL INFORMATION FORM}

\begin{tabular}{|c|c|c|c|c|c|c|}
\hline Your Gender & Female $\square$ & \multicolumn{2}{|l|}{ Male $\square$} & & & \\
\hline $\begin{array}{l}\quad \text { Your } \\
\text { Father's } \\
\text { Education }\end{array}$ & $\begin{array}{l}\text { Can't Read } \\
\text { and Write } \square\end{array}$ & \begin{tabular}{l}
\multicolumn{1}{c}{ Primary } \\
School \\
Graduate $\square$
\end{tabular} & \begin{tabular}{l}
\multicolumn{1}{c}{ Middle } \\
School \\
Graduate
\end{tabular} & \begin{tabular}{l}
\multicolumn{1}{c}{ High } \\
School \\
Graduate
\end{tabular} & $\begin{array}{c}\text { License } \\
\text { Graduate } \square\end{array}$ & $\square^{\text {Postgraduates }}$ \\
\hline $\begin{array}{l}\text { Your } \\
\text { Mother's } \\
\text { Education }\end{array}$ & $\begin{array}{l}\text { Can't Read } \\
\text { and Write } \square\end{array}$ & \begin{tabular}{l}
\multicolumn{1}{c}{ Primary } \\
School \\
Graduate $\square$
\end{tabular} & \begin{tabular}{l}
\multicolumn{1}{c}{ Middle } \\
School \\
Graduate $\square$
\end{tabular} & \begin{tabular}{l}
\multicolumn{1}{c}{ High } \\
School \\
Graduate $\square$
\end{tabular} & $\begin{array}{c}\text { License } \\
\text { Graduate } \square\end{array}$ & $\begin{array}{l}\quad \text { Postgraduates } \\
\square\end{array}$ \\
\hline
\end{tabular}




\begin{tabular}{|l|l|l|l|l|l|}
\hline $\begin{array}{c}\text { Monthly } \\
\text { Revenues }\end{array}$ & $\begin{array}{c}0-1000 \\
\text { TRY } \square\end{array}$ & 1001-2000 TRY $\square$ & $\begin{array}{l}\text { 2001- } \\
3000 \text { TRY } \\
\square\end{array}$ & $\begin{array}{c}3001- \\
4000 \text { TRY } \square\end{array}$ & $\begin{array}{c}4000 \text { TRY - } \\
\text { More }\end{array}$ \\
\hline
\end{tabular}

1. Your teacher asked you to create a humorous cartoon to use Turkish words taken from foreign languages and not yet settled in our language. Draw a cartoon for this purpose.

2. You are asked to create two cartoons that reveal that sport is important to human life. The first of these cartoons will be prepared for girls in Africa and the other will be prepared for boys in your own country. Draw these two cartoons below.

3. Read the following text. After reading, draw a cartoon that addresses the event in the text.

Once upon a time, Nasreddin Hodja was going home with his son on the donkey. Time passed. A group of people got in front of them. One of them said, " Isn't it a shame Hodja, how can a donkey bear so much burden?," he said. Nasreddin Hodja took his son off the donkey and moved on. After a while, another man said, " Shame Nasreddin Hodja shame. Is the little boy forced to walk?, " he said. Nasreddin Hodja put the boy on a donkey. Continued on their way. Time passed again and another man said, "That's it the children of this time, the old fathers walk but they ride the donkey., " he said. That word upset the boy and he gets off the donkey. Now they're both gone on foot. A chatty man said, " Look at the fools, the donkey is leading the way, they are walking on foot., " he said. Then Nasreddin Hodja said, " you see, my son, the mouth of the others are not a bag., " he said.

4. During the day we often encounter people who do not comply with traffic rules. Draw a cartoon that reveals the situation caused by people not following the rules even though they should.

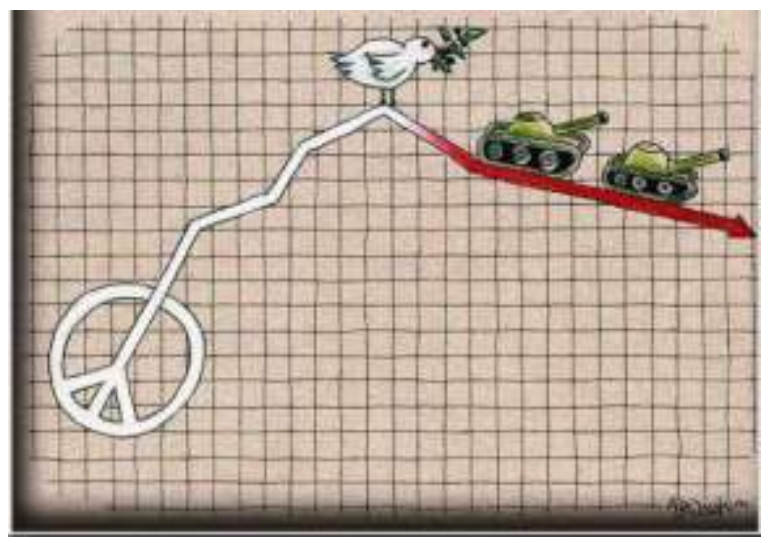

5. Review the cartoon. Create a paragraph of text based on the Post-review cartoon.

Line: It is a one-dimensional structure that moves the eye in a specific area or around an area, dragging attention along a path or drawing it to a point. Horizontal lines give a feeling of stagnation. Vertical lines show strength, feel upward. Diagonal lines give a strong sense of movement and dynamism.

Shape: A line that connects to itself forms a shape. The figures are two-dimensional and can show the outlines of an object.

Light: It is the value that connects the parts between the light (bright) parts and the shaded (dark) parts of the objects in a precise transition.

6. Using the visual art elements and design principles given above, draw a cartoon on a subject you want. 


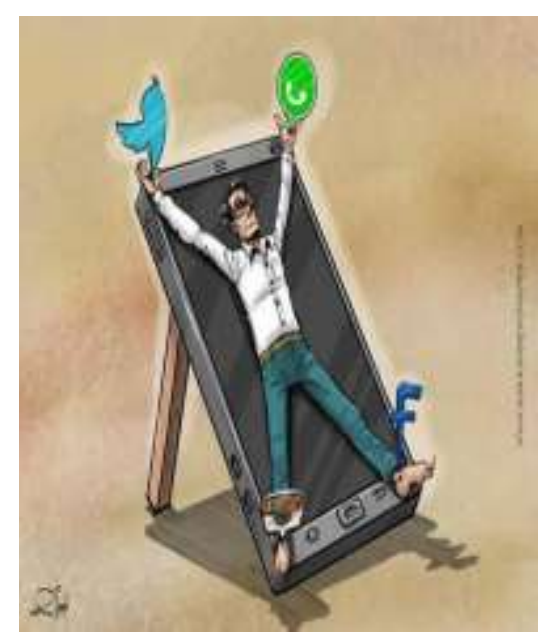

your attention recently.

7. Review the cartoon near. Identify the message the cartoon gives. You can also draw a cartoon with a similar message from the cartoon below.

8. What kind of caricature do you draw to enrich this poster when you are asked to make a banner suitable for the theme of Health and sport as a project task? Draw the cartoon you designed.

9. Plot a cartoon that reveals the event and situation that has attracted

10. You listen to "Mehmetçik" song evokes the feelings and thoughts you express by drawing a cartoon. Internet address of the song: https://www.youtube.com/watch?v=YDWj9Dx3piA

All bad habits begin first by being told what will happen once. So is smoking. For some, smoking; is to grow, to prove himself. The cigarette slowly drains its venom. You say "I'll quit if I want to.". You don't realize it, but now you're a prisoner of smoking.

11. Express the emotion and thought that the above text evokes in you by drawing cartoons.

12. In any period of your life, you can express the feelings and thoughts aroused by an event that you have witnessed or passed through your head by drawing a cartoon.

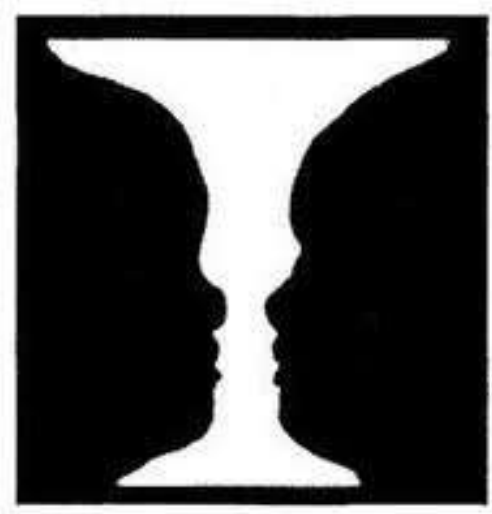

\section{Shape-Ground Relationship}

When you look at the picture near, do you see a vase or two people looking face-to-face? We perceive the basic stimulus that enters our perception field as "shape" and the environment that surrounds it as "ground".

13. Similarly, you create an example of the shape - ground relationship.

14. Consider yourself a candidate to be a school representative. Imagine designing banners to impress people. Draw a cartoon that states that the vast majority in the school want to elect you President, and that undecided students need to vote for you like the others if they want to be on the winning side. 


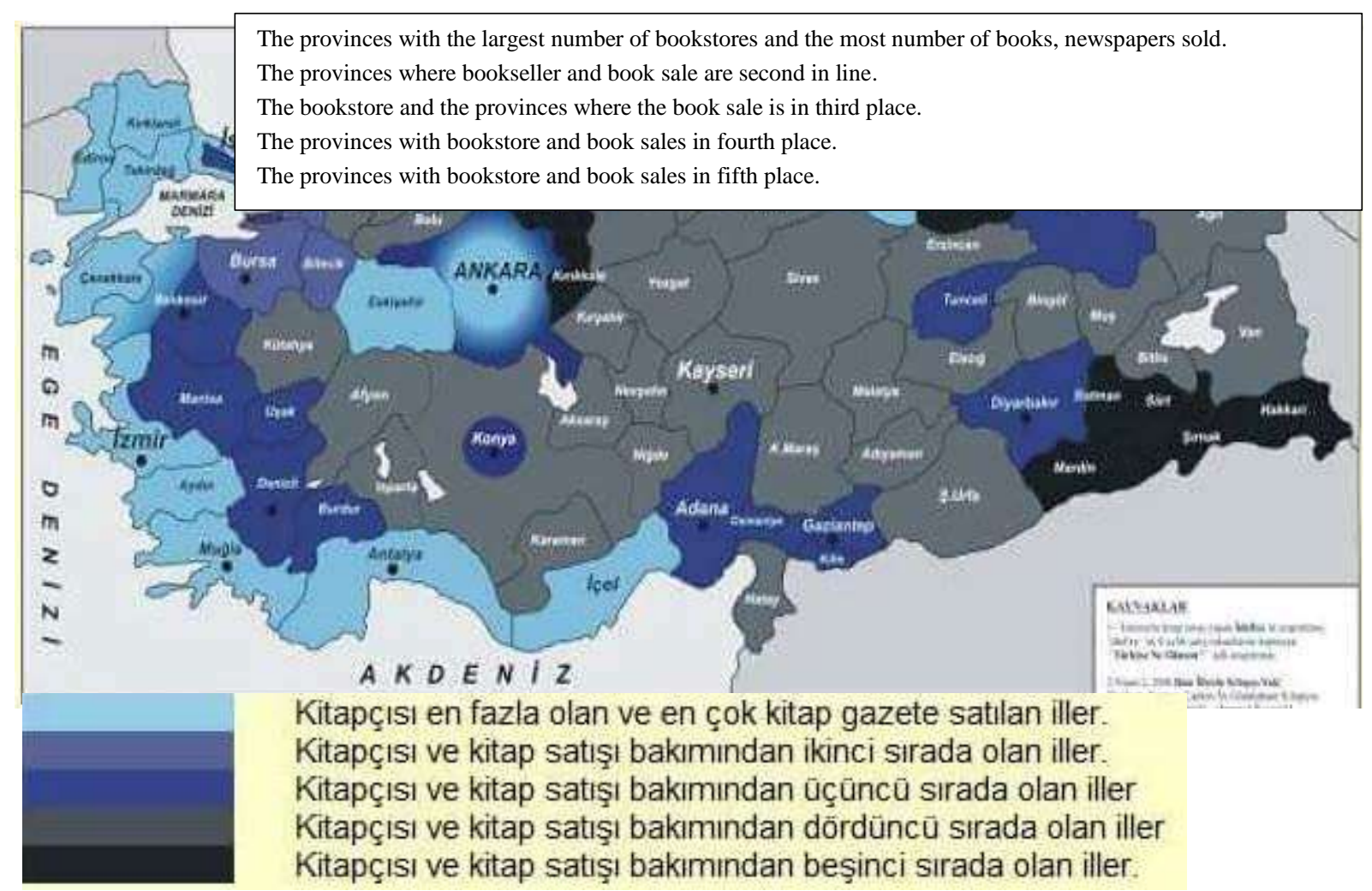

15. Above is a map showing the number of bookstores and book sales. According to the map, our province ranks fourth in terms of Afyonkarahisar bookstore and book sales. Eskisehir Bookstore, one of our neighboring provinces, ranks first in terms of book sales; Denizli, Burdur and Uşak bookstore ranks third in terms of book sales. Draw a cartoon that provides information about the ranking of Afyonkarahisar, Eskişehir, Denizli, Burdur and Uşak provinces in terms of bookstore and book sales.

16. The first of the healthy eating cartoons given below is taken from the Turkey addiction and struggle Education Program site and the other is taken from any website. Take advantage of these cartoons to draw a cartoon. 

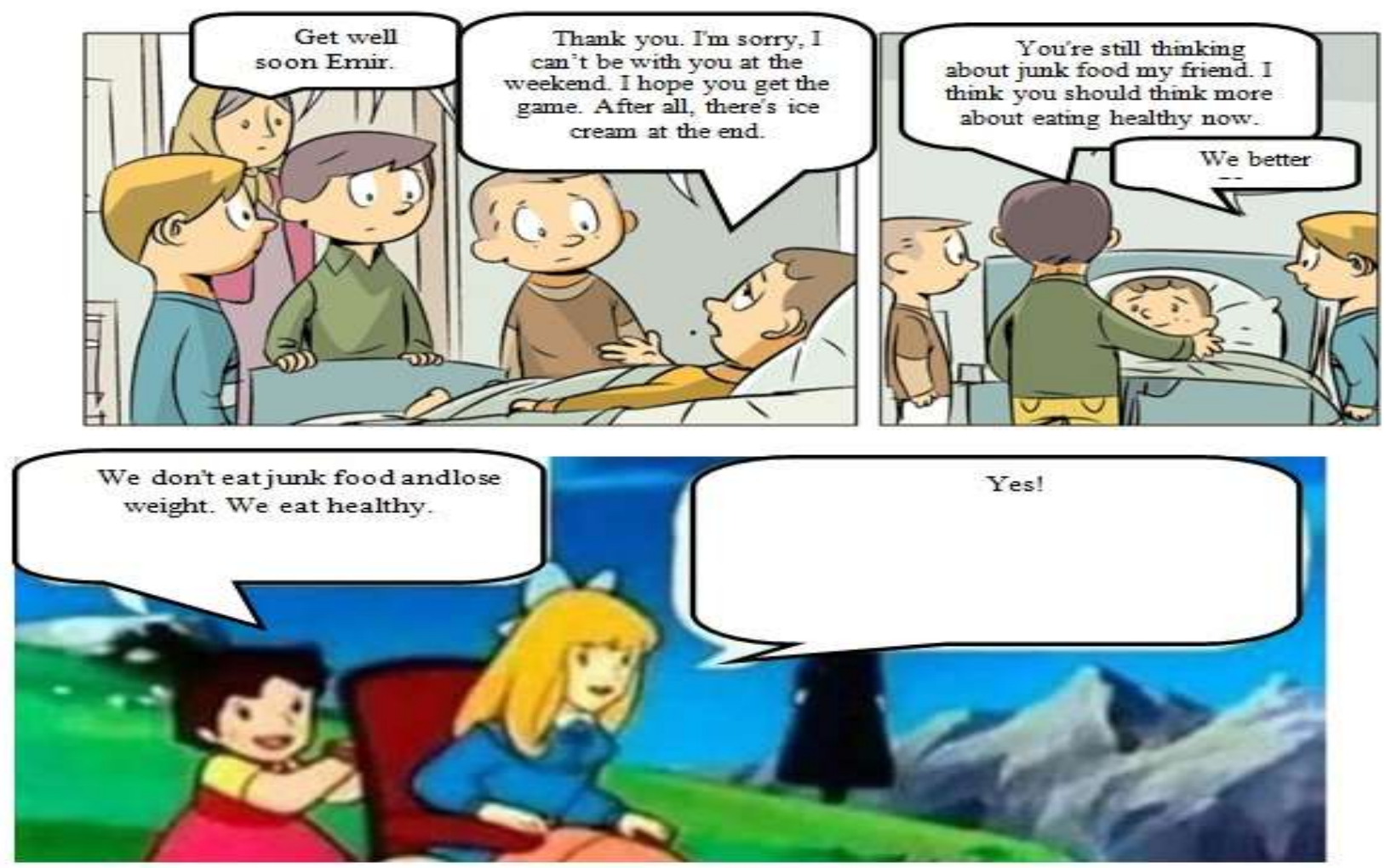

17. You are conducting a research on the rate of air pollution in Afyonkarahisar. During your research, you have received two pieces of information. Your father stated that there is very little air pollution in Afyonkarahisar. According to the latest report of the World Health Organization (who), the threshold values for air pollution in 6 cities of Turkey have been exceeded 4-5 times; Igdir, Batman, Afyon, Osmaniye, Gaziantep, Siirt inhale poison Ministry of Environment and Urban Planning "www. csb.gov.tr " you learned from your address. Drawing a cartoon with air pollution rate in Afyonkarahisar based on the information obtained during the research.

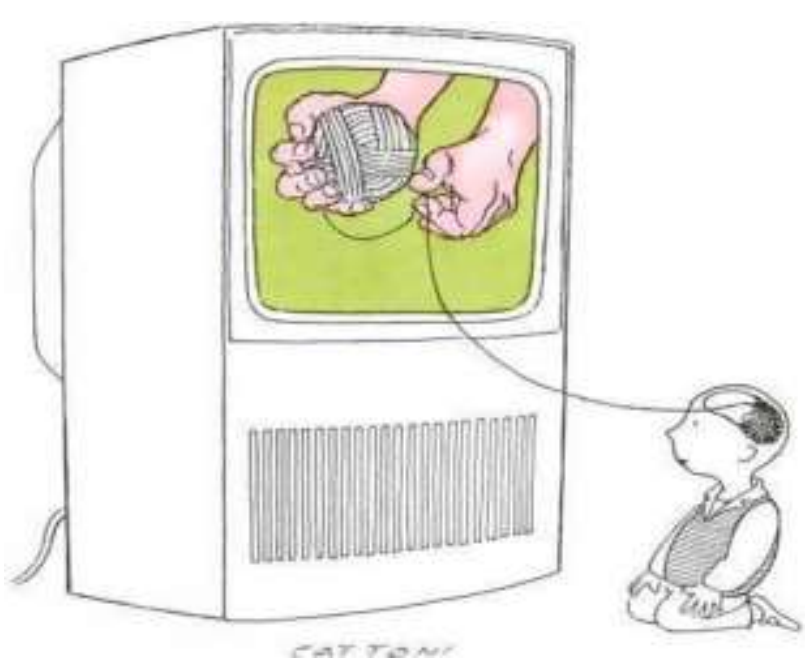

18. The cartoon given on the side was made by the world-famous cartoonist Cattoni. This cartoon about technology addiction has received awards and has been one of the best cartoons in the world. So much so that the country's president has even awarded Cattoni the Outstanding Service Medal for making the best cartoon that can be made about technology addiction. Asked about the reason for his success, Cattoni told reporters that while creating my cartoons I would not imitate anyone, what is already important is to be able to look at the same thing differently. And you draw a cartoon about technology addiction. 


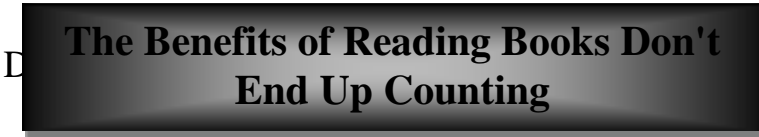
on the "importance of reading books" given below.
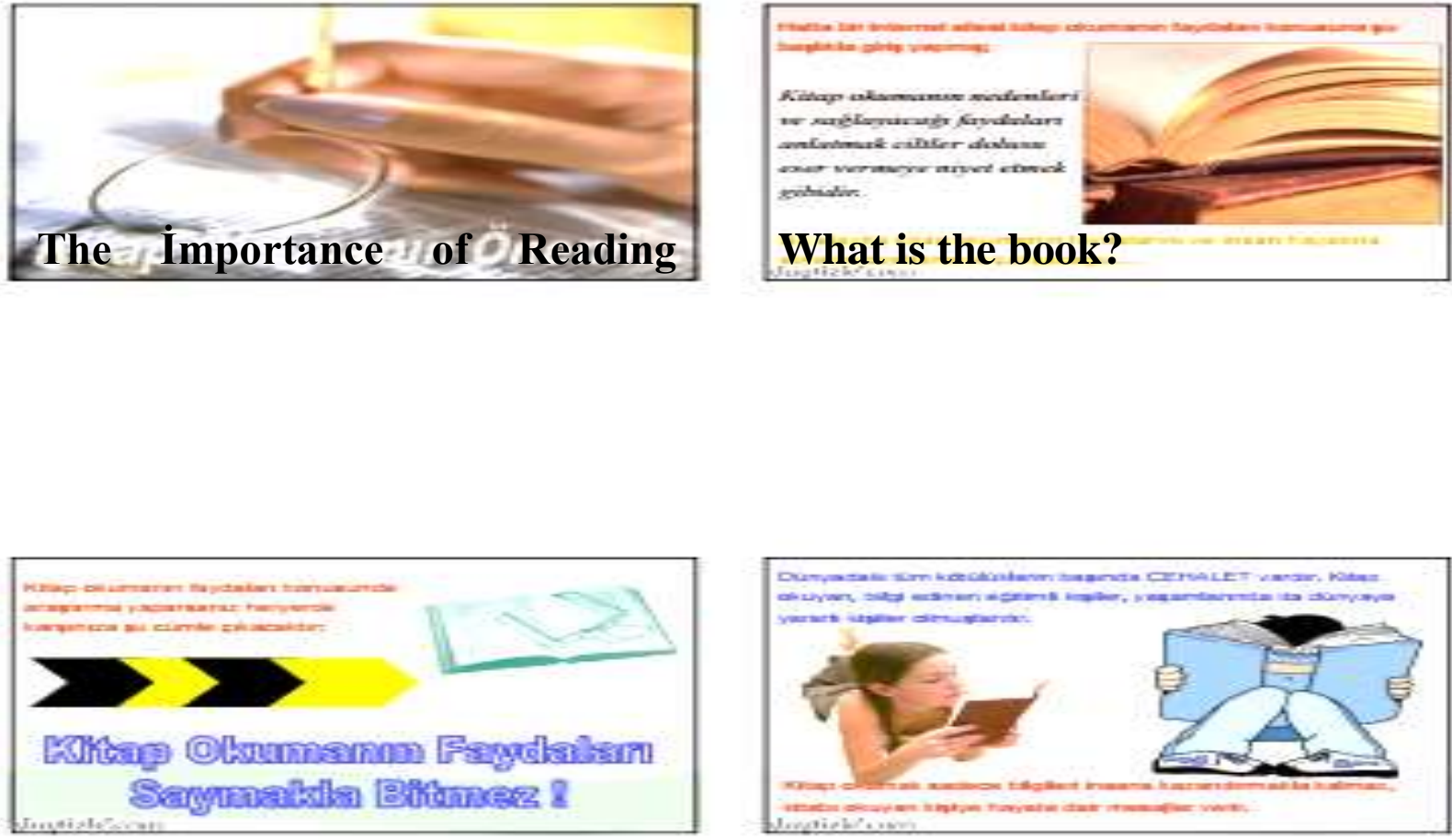

\section{B. Carıcature Literacy Key To Scoring Skills In Carıcature Creatıon}

\begin{tabular}{|c|c|c|c|c|c|c|c|}
\hline \multirow{5}{*}{ 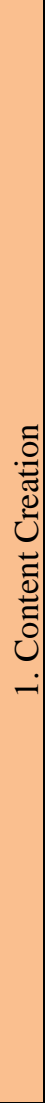 } & & \multirow[b]{2}{*}{ Criteria } & \multicolumn{5}{|c|}{ Levels Of Success } \\
\hline & & & $\begin{array}{l}\text { Significant Lack of } \\
\text { Performance (1) }\end{array}$ & $\begin{array}{l}\text { Limited Performance } \\
\text { to Improve (2) }\end{array}$ & $\begin{array}{c}\text { Successful } \\
\text { Performance (3) }\end{array}$ & $\begin{array}{c}\text { Excellent } \\
\text { Performance (4) }\end{array}$ & Score \\
\hline & 1 & $\begin{array}{c}\text { Purpose-Built } \\
\text { Cartoon } \\
\text { Creation }\end{array}$ & $\begin{array}{l}\text { She/He has not created } \\
\text { cartoons in line with his } \\
\text { purpose and need. The } \\
\text { subject of the created } \\
\text { cartoon is completely } \\
\text { out of the main idea } \\
\text { purpose and need. }\end{array}$ & $\begin{array}{l}\text { She/He created } \\
\text { cartoons in line with } \\
\text { his purpose and need. } \\
\text { The subject of the } \\
\text { created cartoon } \\
\text { partially coincide } \\
\text { with the main idea } \\
\text { purpose and need. }\end{array}$ & $\begin{array}{l}\text { She/He created } \\
\text { cartoons in line } \\
\text { with his purpose } \\
\text { and need. The } \\
\text { subject of the } \\
\text { created cartoon } \\
\text { largely coincide the } \\
\text { main idea with } \\
\text { purpose and need. }\end{array}$ & $\begin{array}{l}\text { She/He created } \\
\text { cartoons in line } \\
\text { with his purpose } \\
\text { and need. The } \\
\text { subject of the } \\
\text { created cartoon } \\
\text { coincide with the } \\
\text { main idea and } \\
\text { purpose. }\end{array}$ & \\
\hline & 2 & $\begin{array}{l}\text { Considering } \\
\text { the Target } \\
\text { Audience }\end{array}$ & $\begin{array}{l}\text { It has never take into } \\
\text { consideration the } \\
\text { characteristics of the } \\
\text { target audience (gender, } \\
\text { age, community) when } \\
\text { creating cartoon. }\end{array}$ & $\begin{array}{l}\text { It partially took into } \\
\text { account the } \\
\text { characteristics of the } \\
\text { identified target group } \\
\text { (gender, age, } \\
\text { community) in } \\
\text { creating the cartoon. }\end{array}$ & $\begin{array}{l}\text { It has largely taken } \\
\text { into account the } \\
\text { characteristics of } \\
\text { the set identified } \\
\text { target group } \\
\text { (gender, age, } \\
\text { community) when } \\
\text { creating cartoon. }\end{array}$ & $\begin{array}{l}\text { It has largely taken } \\
\text { into account the } \\
\text { characteristics of } \\
\text { the set identified } \\
\text { target group } \\
\text { (gender, age, } \\
\text { community) when } \\
\text { creating cartoon. }\end{array}$ & \\
\hline & 3 & $\begin{array}{c}\text { Selecting the } \\
\text { Appropriate } \\
\text { Cartoon Type } \\
\text { for the } \\
\text { Specified } \\
\text { Purpose } \\
\end{array}$ & $\begin{array}{l}\text { The type of the created } \\
\text { cartoon and the purpose } \\
\text { of creating the material } \\
\text { do not coincide. }\end{array}$ & $\begin{array}{l}\text { The type of created } \\
\text { cartoon and the } \\
\text { purpose of creating } \\
\text { the material partially } \\
\text { coincide. }\end{array}$ & $\begin{array}{l}\text { The type of created } \\
\text { cartoon and the } \\
\text { purpose of creating } \\
\text { the material largely } \\
\text { coincide. }\end{array}$ & $\begin{array}{l}\text { The type of created } \\
\text { cartoon and the } \\
\text { purpose of creating } \\
\text { the material } \\
\text { completely coincide } \\
\text {. }\end{array}$ & \\
\hline
\end{tabular}




\begin{tabular}{|c|c|c|c|c|c|}
\hline 4 & $\begin{array}{l}\text { Using the } \\
\text { Refraction } \\
\text { Lines of the } \\
\text { Cartoon }\end{array}$ & $\begin{array}{l}\text { The Created cartoon in } \\
\text { line with its purpose } \\
\text { and the cartoon's } \\
\text { refractive lines (humor, } \\
\text { exaggeration, } \\
\text { opposition) do not } \\
\text { coincide. }\end{array}$ & $\begin{array}{l}\text { The cartoon created in } \\
\text { line with the purpose } \\
\text { of the cartoon's } \\
\text { refractive lines } \\
\text { (humor, exaggeration, } \\
\text { opposition) partially } \\
\text { coincide. }\end{array}$ & 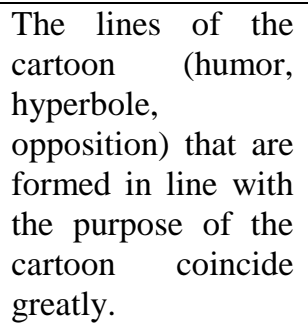 & $\begin{array}{l}\text { The cartoon created } \\
\text { in line with the } \\
\text { purpose of the } \\
\text { cartoon's refractive } \\
\text { lines (humor, } \\
\text { hyperbole, } \\
\text { opposition) } \\
\text { completely coincide }\end{array}$ \\
\hline 5 & $\begin{array}{l}\text { Creating Text } \\
\text { Based on } \\
\text { Cartoon }\end{array}$ & $\begin{array}{l}\text { The text created is } \\
\text { incompatible with the } \\
\text { emotion and thought of } \\
\text { the cartoon. }\end{array}$ & $\begin{array}{l}\text { The text created is } \\
\text { partially compatible } \\
\text { with the emotion and } \\
\text { thought of the } \\
\text { cartoon. }\end{array}$ & $\begin{array}{l}\text { The text created is } \\
\text { largely in line with } \\
\text { the emotion and } \\
\text { thought of the } \\
\text { cartoon. }\end{array}$ & $\begin{array}{l}\text { The text created is } \\
\text { entirely in line with } \\
\text { the emotion and } \\
\text { thought of the } \\
\text { cartoon. }\end{array}$ \\
\hline 6 & $\begin{array}{l}\text { Using Art } \\
\text { Elements and } \\
\text { Design } \\
\text { Principles }\end{array}$ & $\begin{array}{l}\text { She/He didn't apply art } \\
\text { elements and design } \\
\text { principles (line, shape, } \\
\text { light) in the visual } \\
\text { material he created. }\end{array}$ & $\begin{array}{l}\text { She/He partially } \\
\text { applied art elements } \\
\text { and design principles } \\
\text { (line, shape, light) in } \\
\text { the visual material he } \\
\text { created. }\end{array}$ & $\begin{array}{l}\text { She/He largely } \\
\text { applied art elements } \\
\text { and design } \\
\text { principles (line, } \\
\text { shape, light) in the } \\
\text { visual material he } \\
\text { created. }\end{array}$ & $\begin{array}{l}\text { She/He applied art } \\
\text { elements and design } \\
\text { principles (line, } \\
\text { shape, light) in the } \\
\text { visual material he } \\
\text { created. }\end{array}$ \\
\hline 7 & $\begin{array}{l}\text { Rearrange } \\
\text { Cartoons }\end{array}$ & $\begin{array}{l}\text { She/he could not } \\
\text { structure the given } \\
\text { cartoon and could not } \\
\text { convey her/his } \\
\text { emotions, thoughts, } \\
\text { dreams and } \\
\text { impressions. }\end{array}$ & $\begin{array}{l}\text { By structuring the } \\
\text { given cartoon, she/he } \\
\text { partially successfully } \\
\text { conveyed her/his } \\
\text { emotions, thoughts, } \\
\text { dreams and } \\
\text { impressions. }\end{array}$ & $\begin{array}{l}\text { By structuring the } \\
\text { given cartoon, } \\
\text { she/he has largely } \\
\text { successfully } \\
\text { conveyed her/his } \\
\text { emotions, thoughts, } \\
\text { dreams and } \\
\text { impressions. }\end{array}$ & $\begin{array}{l}\text { She/He successfully } \\
\text { conveyed her/his } \\
\text { emotions, thoughts, } \\
\text { dreams and } \\
\text { impressions by } \\
\text { structuring the } \\
\text { given cartoon. }\end{array}$ \\
\hline 8 & $\begin{array}{l}\text { Creating } \\
\text { Cartoons that } \\
\text { Fit the Theme } \\
\text { and Subject }\end{array}$ & $\begin{array}{l}\text { She/He didn't consider } \\
\text { the content and theme } \\
\text { set in the cartoon } \\
\text { production. }\end{array}$ & $\begin{array}{l}\text { She/He partially took } \\
\text { into account the } \\
\text { content and theme set } \\
\text { in the cartoon } \\
\text { production. }\end{array}$ & $\begin{array}{l}\text { She/He has largely } \\
\text { taken into account } \\
\text { the content and } \\
\text { theme set in cartoon } \\
\text { production. }\end{array}$ & $\begin{array}{l}\text { She/He took into } \\
\text { account the content } \\
\text { and theme set in the } \\
\text { cartoon production. }\end{array}$ \\
\hline 9 & $\begin{array}{l}\text { Reflection on } \\
\text { the Daily } \\
\text { Cartoon }\end{array}$ & $\begin{array}{l}\text { The cartoon is far from } \\
\text { current, current quality. }\end{array}$ & $\begin{array}{l}\text { The cartoon was } \\
\text { created in part of a } \\
\text { current, } \\
\text { nature. }\end{array}$ & $\begin{array}{l}\text { The caricature is } \\
\text { largely up-to-date, } \\
\text { current in nature. }\end{array}$ & $\begin{array}{l}\text { The cartoon is of a } \\
\text { current, current } \\
\text { nature. }\end{array}$ \\
\hline 10 & $\begin{array}{l}\text { Cartooning } \\
\text { What They } \\
\text { Listen to }\end{array}$ & $\begin{array}{l}\text { She/He could not } \\
\text { caricate what he } \\
\text { listened to the point } \\
\text { that the subject matter } \\
\text { would be the main } \\
\text { idea. }\end{array}$ & $\begin{array}{l}\text { She/He was able to } \\
\text { partially caricature } \\
\text { what she/he was } \\
\text { listening to at a level } \\
\text { that would put it as the } \\
\text { main idea. }\end{array}$ & $\begin{array}{l}\text { She/He was able to } \\
\text { caricaturize what } \\
\text { she/he was listening } \\
\text { to at a level that } \\
\text { would put it as the } \\
\text { main idea. }\end{array}$ & $\begin{array}{l}\text { She/He was able to } \\
\text { caricature what } \\
\text { she/he was listening } \\
\text { to at a level that } \\
\text { would reveal the } \\
\text { subject as the main } \\
\text { idea. }\end{array}$ \\
\hline 11 & $\begin{array}{l}\text { Cartooning the } \\
\text { Text She/He } \\
\text { Read }\end{array}$ & $\begin{array}{l}\text { She/He has not been } \\
\text { able to caricature the } \\
\text { text she/he has read at } \\
\text { the level that would } \\
\text { reveal the subject as the } \\
\text { main idea. }\end{array}$ & $\begin{array}{l}\text { She/He was able to } \\
\text { partially caricature } \\
\text { the text she/he was } \\
\text { reading at a level that } \\
\text { would reveal the } \\
\text { subject as the main } \\
\text { idea. }\end{array}$ & $\begin{array}{l}\text { She/He was able to } \\
\text { caricaturize the text } \\
\text { he read to a great } \\
\text { extent to present the } \\
\text { subject as the main } \\
\text { idea. }\end{array}$ & $\begin{array}{l}\text { She/ He was able to } \\
\text { caricature the text } \\
\text { he read to the point } \\
\text { that the subject was } \\
\text { the main idea. }\end{array}$ \\
\hline
\end{tabular}




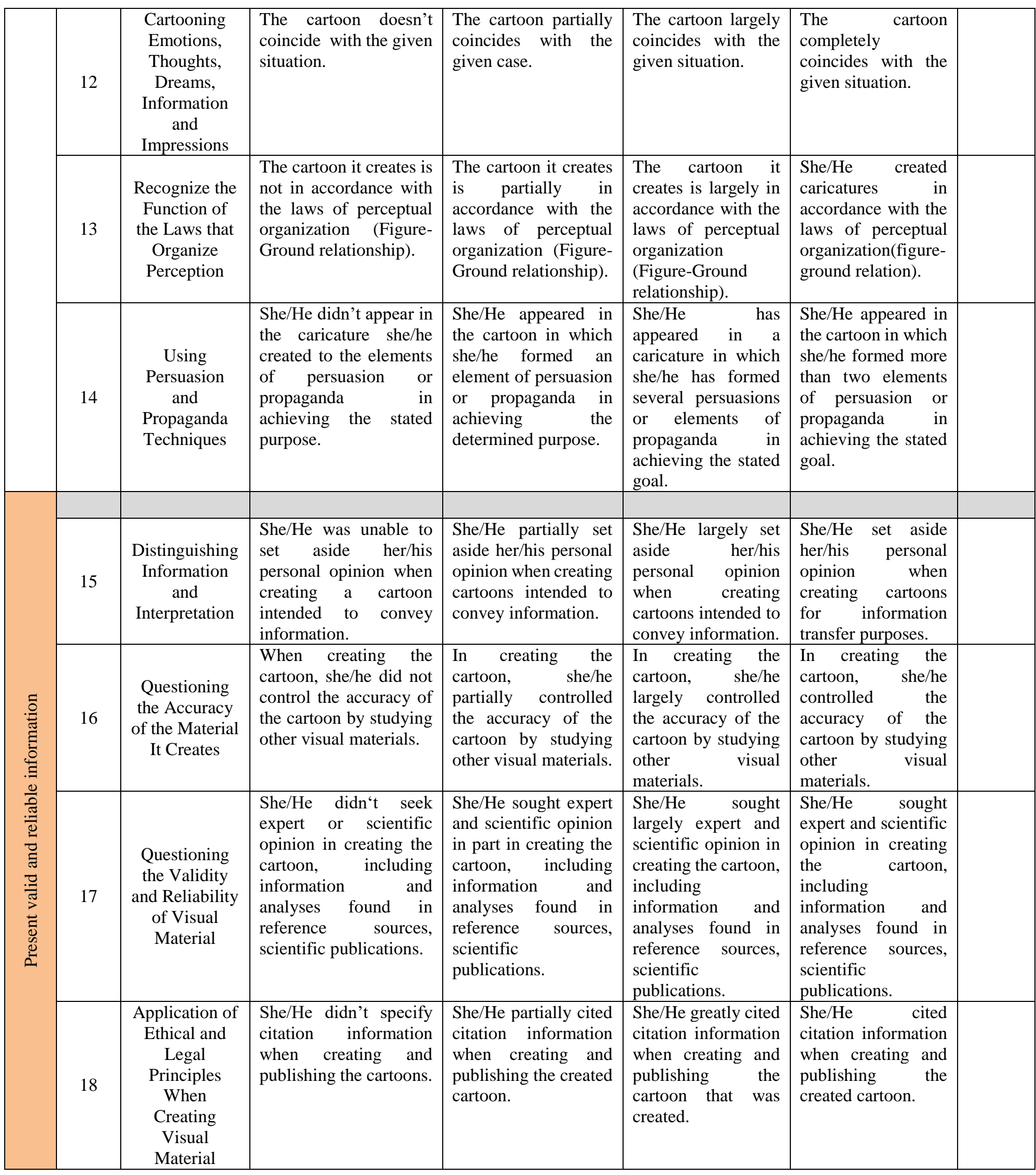




\begin{tabular}{|c|c|c|c|c|c|c|}
\hline 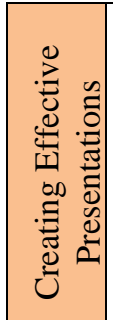 & 19 & $\begin{array}{l}\text { Choosing the } \\
\text { Appropriate } \\
\text { Visual } \\
\text { Materials }\end{array}$ & $\begin{array}{l}\text { She/He was unable to } \\
\text { choose the cartoons that } \\
\text { would enrich her/his } \\
\text { presentation as content. }\end{array}$ & $\begin{array}{l}\text { She/He chose in part } \\
\text { the cartoons that } \\
\text { would enrich her/his } \\
\text { presentation as } \\
\text { content. }\end{array}$ & $\begin{array}{l}\text { She/He has largely } \\
\text { chosen cartoons that } \\
\text { will enrich her/his } \\
\text { presentation as } \\
\text { content. }\end{array}$ & $\begin{array}{l}\text { She/He selected } \\
\text { cartoons that would } \\
\text { enrich her/his } \\
\text { presentation as } \\
\text { content. }\end{array}$ \\
\hline
\end{tabular}

\section{6. sınıf öğrencilerinin karikatür oluşturma becerilerinin değerlendirilmesine yönelik bir dereceli puanlama anahtarı çalışması}

\section{$\ddot{O} \mathbf{z}$}

Araştırmada, 6. sınıf öğrencilerinin karikatür oluşturma süreçleri sonunda ortaya çıkardıkları ürünlerin değerlendirilmesinde kullanılabilecek "Karikatür Oluşturma Rubriği” nin (Analitik dereceli puanlama anahtarı) geliştirilmesi ve geçerlilik güvenirlilik çalışmalarının yapılması amaçlanmıştır.

Dereceli puanlama anahtarında yer alan ölçütler araştırmacı tarafından hazırlanan "Karikatür Okuryazarlığı Modülü"nden yararlanarak belirlenmiştir. Performans tanımlarının ardından çalışma grubu dışındaki başka bir gruba dereceli puanlama anahtarının geçerliğini arttırmak amacıyla pilot uygulama gerçekleştirilmiştir. Pilot uygulama karikatür oluşturma becerisine sahip ve çalışma grubu ile aynı sınıf düzeyinde yer alan altısı kız, biri erkek toplam yedi öğrenci ile gerçekleştirilmiştir. Pilot uygulamadan alınan dönütler doğrultusunda gereken düzeltmeler yapılarak dereceli puanlama anahtarının geçerlik ve güvenirlik çalışmalarının yapılması aşamasına geçilmiştir.

Araştırmacı tarafından özel olarak geliştirilen, karikatür oluşturma becerisini değerlendirmeye yönelik rubriğin güvenirliliğine yönelik yürütülen uygulamadan elde edilen verilerin SPPS 18 programında analizleri yapılmıştır. Puanlama anahtarının güvenirliği için iki farklı değerlendiricinin verdiği puanlar arasındaki tutarlılık incelenmiştir. $\mathrm{Bu}$ amaçla farklı değerlendiricilere göre dereceli puanlama anahtarından elde edilen toplam puanlar arasındaki tutarlılık için pearson momentler çarpım korelasyon katsayısı, her bir alt boyut için puanlamalar arası tutarlılık için ise pearson momentler çarpım korelasyon katsayısı formülü kullanılmıştır.

Sonuç olarak bu araştırmada karikatür oluşturma becerisini değerlendirmeye yönelik geliştirilen rubriğin 6.sınıf öğrencilerinin karikatür oluşturma çalışmalarını ölçme ve değerlendirilmede kullanılabileceği görülmüştür.

Anahtar sözcükler: Karikatür Okuryazarlı̆̆ı, Karikatür Oluşturma, Rubrik/ Dereceli Puanlama Anahtarı

\section{AUTHOR BIODATA}

Musa Çifci is professor at Usak University in Faculty of Education Department of Turkish Language and Social Science Education.

Kadir Kaplan is a PhD student at the Department of Turkish Language Teaching at Uşak University. He has been working as a Turkish teacher at Republic of Turkey Ministry of National Education (MONE) since 2007. He works on the acquisition of four basic language skills, cultural transfer in mother tongue, curriculum programs and textbooks. 